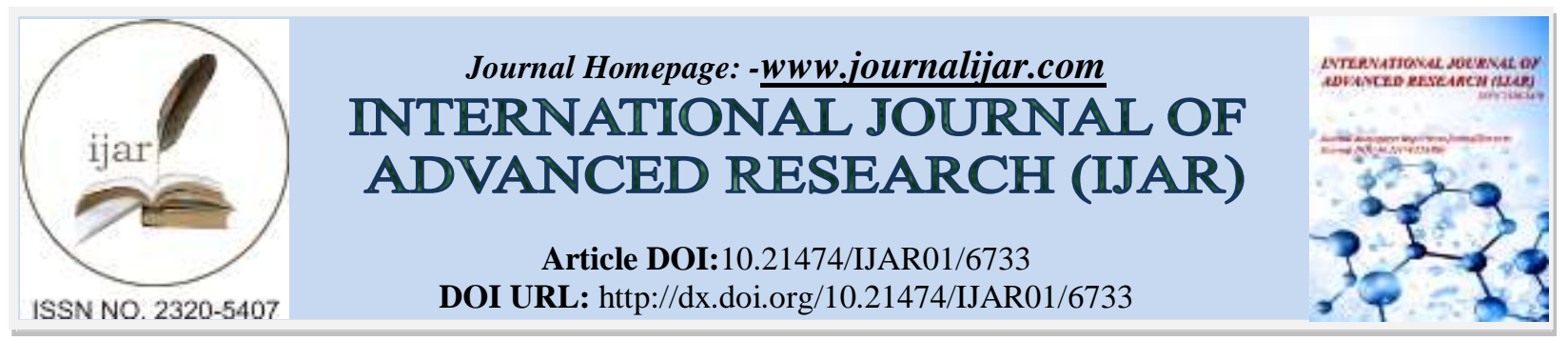

RESEARCH ARTICLE

\title{
IMPACT OF REPLACING COTTON SEED MEAL BY JOJOBA MEAL ON WOOL CHARACTERISTICS IN BARKI SHEEP.
}

\author{
W. A. Ramadan. \\ Wool production and technology department, Animal and poultry production division, Desert Research Center.
}

\section{Manuscript Info}

Manuscript History

Received: 13 January 2018

Final Accepted: 15 February 2018

Published: March 2018

Keywords:-

Jojoba, cotton, meal, wool, characteristics, Amino acids.

\section{Abstract}

The study aimed to investigate the effect of replacing Cotton seed meal by biologically treated Jojoba (Simmondsia chinensis) meal to determine the effect on wool fiber characteristics and amino acid content of wool fibers at 10,20 and 30\% replacing levels in diets of Barki sheep. Forty-eight female Barki sheep were randomly allocated into four experimental groups (12 animals in each) to study wool characteristics. All groups feed the same diet with different replacing levels (cotton seed meal by biologically treated jojoba meal). The first group was the control group fed concentrate feed mixture contain (30\% cotton seed meal), second group (T1) was fed concentrate feed mixture contain ( $20 \%$ cotton seed meal $\pm 10 \%$ treated jojoba meal), third group (T2) was fed concentrate feed mixture contain (10\% cotton seed meal \pm $20 \%$ treated jojoba meal and the fourth group (T3) was fed concentrate feed mixture contain ( $30 \%$ treated jojoba meal).

Results showed that kemp fiber \% (KF \%), crimp frequency (CF), staple length (STL), staple strength (STR), staple elongation \% (STE\%), point of break (POB) and wool production per unit area (WP) were not differ significantly among treatment groups and control, while, fiber diameter (FD), fine fibers \% (FF\%), coarse fibers \% (CF\%), clean scoured yield \% (YLD\%) and cotting score (CS) were differ significantly $(\mathrm{P}<0.05)$ among treatment groups and control. Glycine (Gly), Methionine (Met), Leucine (Leu) and Proline (Pro) were significantly $(\mathrm{P}<0.05)$ differ among treatment groups and control, while the rest of amino acids were not differ among treatment groups and control.

Copy Right, IJAR, 2018,. All rights reserved.

\section{Introduction:-}

The shortage in local animal fodders production coupled with increased demand and competition for its use in livestock has further increased animal feedstuff prices. Jojoba (Simmondsia chinensis) is a perennial shrub that grows naturally in the Sonora desert (Mexico) and in the South-West of USA. Jojoba is now cultivated in some countries: Argentina $\left(2.0 \mathrm{kt} \mathrm{yr}^{-1}\right)$, Israel $\left(1.1 \mathrm{kt} \mathrm{yr}^{-1}\right)$, USA $\left(1.0 \mathrm{kt} \mathrm{yr}^{-1}\right)$ and some Mediterranean and African lands are the main seed producers (data are for the campaign 2002-03). Several advantages are favoring Jojoba seed to be grown in Egypt such as limited water requirements, high seed yield in new reclaimed soils and relatively high oil content, 50\% (Wisniak, 1987). Jojoba is difficult to be used as animal feed because of the presence of several anti-nutritional factors, such as simmondsin and simmondsin-2-Ferulate and other anti-nutrition 
compounds, polyphenolic, phytic acid and trypsin inhibitors, which reduce feed intake, body weight gain, and biochemical parameters (Van Boven et al.,2000; Sobhy., et al., 2003; Khalel et al.,2008 and Khayyal et al., 2009). Jojoba meal, a by-product of the oil extraction, contains 25 to $33 \%$ protein (Verbiscar and Banigan, 1978 and Motawe, 2005), but its toxic or anti nutritive compounds or both make it unsuitable for lives lock feeding. Indeed, feeding it to lambs (Manos et al., 1986). The meal resulting after oil removal comprises 50\% of the seed which represent a potential amendment for animals/or humans. Fungal treatment of Jojoba meal decreased simmondsin as the major toxicant compound by $98 \%$ and polyphenolic by about $71 \%$, improved feed intake, body weight gain, and feed efficiency of rabbit fed diet containing 10\% jojoba meal (Khayyal et al., 2009). Cardoso (1980) and Ngou Ngoupayou (1982) stated that the acidic amino acids (Aspartic acid, Glutamic acid) were the most plentiful, and the sulfur amino acids (which are very important to wool) were deficient in Jojoba.

Wool is not a uniform biological product because its physical characteristics vary depending on sheep genetics, environment and management strategies (Warn et al., 2006; Poppi and McLenan, 2010). Wool value linked to its characteristics and the ability to meet commercially pre-determined parameters (Wood, 2003; Jones et al., 2004; Purvis and Franklin, 2005; Bidinost et al., 2008). The quality of wool has determined by the physical and mechanical properties: diameter (fineness), length, crimp, strength and elongation of the wool fibres (Ružić-Muslić, 2006). In addition, these properties have ascertained by factors of genetic and paragenetic nature. The most important characteristic of wool is definitely diameter (fineness) fibres. Fiber diameter is widely acknowledged as the most important wool characteristics when assessing wool quality and value (Edriss et al., 2007; Kelly et al., 2007; Rowe, 2010) accounting for approximately 75\% of the total price of raw wool (Jones et al., 2004; Mortimer et al., 2010). Growth of lamb wool fibre is a continuous process influenced by: a genetic basis, nutrition, general physiological status and different environmental factors. The potential of sheep for wool production was determined during their embryonic development. During intrauterine development of lambs, begins the formation of the hair, to the extent of which depends on the genetic potential of the animal. The number and size of wool fibres produced by follicles (structural units in the skin of sheep) determine the quantity of wool produced. Primary follicles occur in the skin of the foetus on the ninetieth day after fertilization, while the secondary follicles develop from that moment on until the birth of lambs (Jovanović et al., 2001). The volume of maturation of follicles and production of wool fibres have closely related to nutrition and intensity of lamb growth. Because the wool fibre is a protein matter whose main ingredient is keratin, the presence and source of protein in the diet affect the yield and quality of fiber (Zeremski et al., 1989). The objective of the present study aims to evaluate the partial replacement (10, 20 and 30 $\%$ ) of cottonseed meal by biologically treated Jojoba meal on wool characteristics and amino acids content of wool fibers.

\section{Materials and Methods:-}

The Present study was conducted at Maryot Research Station which belonging to Desert Research center (DRC), Egypt. Jojoba meal (JM) (Simmondsia chinensis) samples were graciously supplied by the Egyptian natural oil company (private sector). Forty-eight female Barki sheep at 3-4 years old with an average weight of $34.55 \pm 2.28 \mathrm{~kg}$ were randomly allocated into four experimental groups (12 animals in each) to study wool characteristics under four feeding treatments, concentrate feeds were calculated and formulated depending on the physiological status of female sheep. The experiment was lasted for six months. Nutrients requirement were calculated according to Kearl (1982) in table (1).

\section{Jojoba treatment:-}

Pure strain of Asperigullis oryzae Fk-923 was obtained from microbial chemistry, National Research Centre, Dokki, Giza, Egypt, the cultures were maintained on-potato-dextrose medium Czabexs Dox Agar according to Oxoid (1982). This was activated in sterilized conical flasks kept in shaker water bath at 28 to 32 C for 96 hours. Fresh liquid culture of Aspergllus Oryzae was obtained by growing on nutrient broth. The active liquid Fungal medium was used to inoculate an amount of ground moist ended JM at $10 \%(\mathrm{v} / \mathrm{w})$ of the jojoba weight and the whole treated amount was kept under aerobic condition for seven days to obtain a sufficient amount of a solid state fermented jojoba meal. The scaling up of the fungal biomass under the farm condition was carried out as described by ElBadawi et al (2007).

\section{Wool characteristics:-}

Wool qualitative parameters were determined for wool samples. Ten staples were taken randomly from each wool sample to measure staple length, to the nearest $0.5 \mathrm{~cm}$, using a ruler. Length measured from the bottom until the dense part of the staple end according to Chapman (1960). Five hundred fibers, from each sample, were used to 
estimate the average fiber diameter using Carl-Zeiss Micro Imaging device with optical fiber diameter image analyzer software, Zen (Blue edition), with lens 10/0.847 according to ASTM-D2130 (ASTM, 2014). Three greasy staples of each sample were used to measure staple strength using Agritest Staple Breaker with the procedure displayed by El-Gabbas et al., (1999). Elongation, representing the increase in staple length as proportion of the original length, was measured. Point of break, by weight and by length (the weight and length of top in proportion to the weight and length of both top and base) were calculated at the time of measuring staple strength. Sub samples, not less than 300 fibers, were classified into kemp, medullated and fine fiber categories; according to its coarseness and the percentage of medulla. Wool fibers contained very coarse fibers with medulla occupying more than $70 \%$ of the medullated fiber are classified as kemp and fibers contained medulla classified as coarse fiber, whereas other non-medullated fibers classified as fine or non-medullated fibers Guirgis (1973). Crimp frequency (CF) is calculated as the average number of crimps per one centimeter of un-stretched fibers.

Wool quantitative traits were determined in this study. Wool production per unit area was measured by greasy wool weight in square $10 * 10 \mathrm{~cm}$ area. Clean scoured yield was calculated using the method suggested by Chapman (1960). In addition, cotting score was determined as subjective estimates. According to El-Gabbas (1993), subjective graduation measurement was used to record a cotting trait of wool, which means the matting of different fibers in the fleece together. Cotting score was determined in a scale of 1-4 points for each sample (higher points indicate a superior cotting). The average cotting scores were recorded for each sample.

\section{Amino acids analysis in wool:-}

The acid hydrolyzed amino acids by amid bond breakage were determined according to Pellet and Young (1980) as follows: Diethyl ether was used for defatting $1 \mathrm{~g}$ from each dry wool sample. Five $\mathrm{ml}$ of $6 \mathrm{~N}$ hydrochloric acid was used to hydrolyze $0.4 \mathrm{~g}$ in evacuated sealed test tube made of Pyrex at $110^{\circ} \mathrm{C}$ for 24 hours. Hydrolysate was transferred to containers quantitively at the end of the period. Hydrochloric acid was evaporated on water bath at 50$60^{\circ} \mathrm{C}$ to dryness. Five $\mathrm{ml}$ of distilled water was added to the hydrolysate and then evaporated to dryness to get rid of the excess of hydrochloric acid. Distilled water was added again until the excess of the hydrochloric acid removed completely. Samples were dried for obtaining dry film. The dry film that was obtained was dissolved in a known volume of sample dilution buffer $(0.1 \mathrm{~N}$ sodium acetate buffer, $\mathrm{pH} 2.2)$. Membrane filter $0.22 \mu \mathrm{m}$ was used to filter the solution. The samples were stored in freezer in sealed vials until fractionation of the amino acid by using the amino acid analyzer (Sykam Clarity Amino Acid Analyzer SW, Central Lab of Desert Research Center).

\section{Statistical analysis:-}

SAS (2008) program, utilizing GLM procedure was used to analyze the obtained data and the differences between each two means within each factor were compared using Duncan Multiple Range Test (Duncan, 1955).

\section{Results and Discussion:-}

\section{Jojoba meal and wool characteristics:-}

Table (1) shows the composition and chemical analysis of the experimental diets, which indicates that T3 was the highest crude protein compared with other groups. The studied wool fiber physical characteristics of the all experimental groups are presented in table (2). Between groups, control group (31.97) was higher significantly $(\mathrm{P}<0.05)$ than treatment groups $\mathrm{T} 1, \mathrm{~T} 2$ and $\mathrm{T} 3(27.61,26.57$ and 29.02$)$ respectively in fiber diameter. This result may be due to control group has a highest significant $(\mathrm{P}<0.05)(38.37)$ percent of coarse fibers and a lowest significant $(\mathrm{P}<0.05)(58.26)$ percent of fine fibers compared with treatment groups $(\mathrm{T} 2$ and $\mathrm{T} 3)$ and did not reach to significant level with T1 (66.96). Peterson et al. (1998) and Masters et al. (1998) found insignificant effect of level of feeding on both fleece mean fibre diameter and coefficient of variation in fibre diameter between fibres. Under Egyptian conditions, Ashmawy (1972) found that the difference in medullated fibres percentage between nutritional levels was not significant ( 0.91 for high level vs 1.1 for normal level) in non-pregnant ewes of Fleisch Merino. Control group has significant highest percent $(56.91)(\mathrm{P}<0.05)$ compared with $\mathrm{T} 1$ and $\mathrm{T} 2(49.17$ and 50.62) in clean scoured yield percent and did not reach to significant level with T3 (53.49). Results obtained on Barki sheep showed that more wool yield was obtained when high planes of protein nutrition were used (El-Bittar, 2000)

However, there were differences but not significant between groups in other characteristics, control group was the lowest value compared with other groups in crimp frequency (2.33 vs. 2.44, 2.34 and 2.36) and staple elongation ( 39.66 vs. $44.26,43.72$ and 43.12). On the other hand, control group was the highest value in staple length (8.03 vs. $7.68,7.32$ and 7.70), wool production per unit area (10.64 vs. 9.09, 9.96 and 10.20) and staple strength (18.28 vs. 
17.86, 17.38 and 18.12). Urbaniak (1994) indicated that with the increase in protein levels of 9.3 to $15.9 \%$ in the diets for sheep, a linear increase in the production of wool. On the other hand, Pajak et al. (1992) had found that the decrease in protein content in the diet for nutrition of lambs $(17,14$ and $11 \%)$ resulted in a decrease in wool production. In addition, Slen (1969) found that increase of protein levels from 7 to $10 \%$ in dry matter diet used for feeding sheep, has resulted in an increase in production of greasy wool by $16 \%$. At the same time, influenced by the above nutrition treatment, in terms of length and thickness of wool fibre. Ralph (1984) also found a general pattern in which staple strength and staple length tended to increase as the level of supplement increased. T2 was the highest value compared with control, T1 and T3 groups respectively in point of break (48.25 vs. 47.09, 47.34 and 42.60). Whereas, T1 was the highest value compared with other groups in staple elongation percentage (44.26 vs. 39.66 , 43.72 and 43.12), While T1 has a lowest percent (1.47) compared with other groups in kemp fibers. For subjective estimates, cotting in fibers was significantly higher in T2 compared with control and T3 groups and this may be due to the lack of sulfur amino acids in jojoba, which is replaced by cottonseed meal in T2 by $20 \%$. Ryder and Thea (1984) and wood (2003) reported that the level of sulphur in the diet has an effect on the ability to felt through its influence on the plasticity of wool, thus, feeding extra sulphur can reduce the ability to felt.

\section{Jojoba meal and wool amino acids:-}

In spite of fiber types and treatment, data in (table, 3) showed that amino acids; Glutamic , Aspartic and Lysine were present in considerable relatively higher amounts than others (13.58, 10.01 and 9.81 residue/100), while Methionine was the lowest amount in all fibers (0.39 residue/100) and the rest of amino acids were present in moderate amounts. Generally, in the present study the treatment caused a slight increase in most of fiber amino acids contents for T1, T2 and T3 as compared with control while control group was slightly higher than treatment group in fiber amino acid; Serine, Isoleucine, Phenylalanine and Arginine. The overall mean of fiber amino acids composition illustrated that there were significant differences in Glycine, Methionine, Leucine and Pro between all groups. This result could refer to the treatment rations that could increase feed intake causing an increase in amino acids content particularly in T3 that fed 30\% Jojoba. Jovanović et al. (2001) point out that the amount of available amino acids containing sulphur is one of the most important nutritional factors that affect the production and quality of wool. Proteins that avoid bacterial hydrolysis in the rumen (undegradable protein), increase the wool production through increase in supply of the organism with amino acids, especially cystine, which is a limiting factor for the production of wool. According to the same author, the infusion of cystine into abomasum or blood can double the growth of wool, while the infusion of methionine increases the wool growth by providing sulphur for the synthesis of cystine. Table (3) summarized the changes in amino acids composition of both coarse and fine fibers in all experimental groups. Fine fibers have higher value than coarse fibers in most amino acids except Phenylalanine and Lysine. Kulkarni (1980) and Azzam et al. (2002) reported that fine wool had a higher sulphur amino acid content Cystine than that of the coarse fibers. Azzam et al. (2002) found that the fine fibers had higher contents of amino acids, Pro and Cystine than in coarse fibers. There is significant difference between fine and coarse fibers in methionine. These results may be indicating to that Jojoba treated with fungi could increase palatability causing an increment in feed intake and in turn, increasing in amino acids intake. It is well known that Methionine amino acid increased the efficiency of conversion of metabolisable protein to wool and in turn increased wool production (Mata et al. 1995). In addition, Reis (1982) found that methionine has a specific role of in controlling wool growth, other than to provide Cysteine via transulphuration. However, Ward (1998) found that wool contains higher concentrations of serine and Arginine, as well as Cysteine. Serine and Arginine, either alone or in combinations with Methionine or Cysteine increases wool growth.

\section{Correlation between wool amino acids and wool characteristics:-}

Data in table (4) showed that fiber diameter was significant $(\mathrm{P}<0.05)$ positive correlated with Met and Pro, same results was observed by Abd El-Ghany et al., (2012) who found a significant positive correlation between amino acids; Metionine and FD while Cystine and Proline achieved the negative significant correlation with FD. Fine fiber was significant $(\mathrm{P}<0.05)$ positive correlated with Glutamic, Glycine, Cystine, $(\mathrm{P}<0.01)$ Aspartic and significant $(\mathrm{P}<0.05)$ negative correlation with Methionine. On the other hand, coarse fibers was significant $(\mathrm{P}<0.05)$ negative correlation with Glutamic, Glycine, Cystine, $(\mathrm{P}<0.01)$ Asp and significant $(\mathrm{P}<0.05)$ positive correlation with Met. Crimp frequency was significant $(\mathrm{P}<0.05)$ positive correlated with Proline. Staple elongation was significant $(\mathrm{P}<0.05)$ positive correlated with Aspartic, Threonine, Glycine and Tyrosine. Point of break was significant $(\mathrm{P}<0.05)$ positive correlated with Cystine. Clean wool yield $\%$ was significant $(\mathrm{P}<0.05)$ positive correlated with Leucine and Proline. Cotting score was significant $(\mathrm{P}<0.05)$ negative correlated with Lysine. 
Table 1:- The composition and chemical analysis (\% on dry matter basis) of the experimental diets

\begin{tabular}{|c|l|l|l|l|}
\hline \multirow{2}{*}{ Ingredient } & \multicolumn{4}{|c|}{ Experimental groups } \\
\cline { 2 - 5 } & Control & T1 & T2 & T3 \\
\hline Yellow corn\% & 40 & 40 & 40 & 40 \\
\hline Wheat bran\% & 20 & 20 & 20 & 20 \\
\hline Cotton seed meal\% & 30 & 20 & 10 & - \\
\hline Jojoba meal\% & - & 10 & 20 & 30 \\
\hline Molasses\% & 6 & 6 & 6 & 6 \\
\hline Salt\% & 1.5 & 1.5 & 1.5 & 1.5 \\
\hline Limestone\% & 2 & 2 & 2 & 2 \\
\hline Mineral premix\% & 0.5 & 0.5 & 0.5 & 0.5 \\
\hline Chemical composition\% & & & & \\
\hline Dry matter & 90.64 & 90.50 & 90.53 & 90.09 \\
\hline Organic matter & 90.74 & 92.05 & 91.48 & 92.97 \\
\hline Crude protein & 14.31 & 14.00 & 14.22 & 15.78 \\
\hline Ether extract & 2.48 & 2.52 & 3.41 & 4.61 \\
\hline Crude fiber & 8.51 & 7.34 & 6.14 & 4.65 \\
\hline Nitrogen free extract & 65.44 & 68.19 & 67.71 & 66.93 \\
\hline Ash & 9.26 & 7.95 & 8.52 & 7.03 \\
\hline Nitrogen detergent fiber & 31.65 & 30.53 & 24.08 & 23.47 \\
\hline Acid detergent fiber & 17.40 & 15.08 & 13.56 & 10.53 \\
\hline
\end{tabular}

Table 2:- Least square mean \pm S.E. of wool characteristics from different experimental treatments

\begin{tabular}{|l|l|l|l|l|l|}
\hline \multirow{2}{*}{ Traits } & \multicolumn{4}{|c|}{ Experimental groups } & \multirow{2}{*}{ SE } \\
\cline { 2 - 5 } & Control & T1 & T2 & T3 & \\
\hline Qualitative traits & & & & & \\
\hline Fiber diameter, $\mu \mathrm{m}$ & $31.97^{\mathrm{A}}$ & $27.61^{\mathrm{B}}$ & $26.57^{\mathrm{B}}$ & $29.02^{\mathrm{B}}$ & 1.02 \\
\hline Fine fibers\% & $58.26^{\mathrm{B}}$ & $66.96^{\mathrm{AB}}$ & $69.80^{\mathrm{A}}$ & $68.75^{\mathrm{A}}$ & 4.19 \\
\hline Coarse fibers\% & $38.37^{\mathrm{A}}$ & $31.58^{\mathrm{AB}}$ & $27.26^{\mathrm{B}}$ & $27.61^{\mathrm{B}}$ & 3.87 \\
\hline Kemp fibers\% & 3.38 & 1.47 & 2.94 & 3.64 & 0.92 \\
\hline Crimp frequency, n/cm & 2.33 & 2.44 & 2.34 & 2.36 & 0.15 \\
\hline Staple length, cm & 8.03 & 7.68 & 7.32 & 7.70 & 0.56 \\
\hline Staple strength, N/Ktex & 18.28 & 17.86 & 17.38 & 18.12 & 1.33 \\
\hline Staple elongation\% & 39.66 & 44.26 & 43.72 & 43.12 & 2.38 \\
\hline Point of break\% & 47.09 & 47.34 & 48.25 & 42.60 & 2.26 \\
\hline Quantitative traits & & & & & \\
\hline Wool production per unit area, g & 10.64 & 9.09 & 9.96 & 10.20 & 1.02 \\
\hline Clean scoured yield\% & $56.91^{\mathrm{A}}$ & $49.17^{\mathrm{B}}$ & $50.62^{\mathrm{B}}$ & $53.49^{\mathrm{AB}}$ & 2.16 \\
\hline Subjective estimates & & & & & \\
\hline Cotting score & $2.17^{\mathrm{B}}$ & $2.33^{\mathrm{AB}}$ & $2.67^{\mathrm{A}}$ & $2.16^{\mathrm{B}}$ & 0.14 \\
\hline
\end{tabular}

${ }^{\mathrm{A}, \mathrm{B}}$ Capital super script means differences between treatments

Table 3:- Least square mean \pm SE of profile analysis of amino acids present in the wool (residue/100) in coarse and fine wool fibers for the different experimental groups

\begin{tabular}{|c|c|c|c|c|c|c|c|c|c|c|c|c|c|}
\hline \multirow{2}{*}{$\begin{array}{l}\text { Amino } \\
\text { acids }\end{array}$} & \multicolumn{3}{|c|}{ Control } & \multicolumn{3}{|c|}{$\mathrm{T} 1$} & \multicolumn{3}{|c|}{$\mathrm{T} 2$} & \multicolumn{3}{|c|}{ T3 } & \multirow[t]{2}{*}{ pooled } \\
\hline & Coarse & Fine & mean & Coarse & Fine & mean & Coarse & Fine & mean & Coarse & Fine & mean & \\
\hline Aspartic & $\begin{array}{l}9.12 \pm \\
0.44\end{array}$ & $\begin{array}{l}10.03 \pm \\
0.44\end{array}$ & $\begin{array}{l}9.57 \pm \\
0.31\end{array}$ & $\begin{array}{l}9.58 \pm \\
0.44\end{array}$ & $\begin{array}{l}10.56 \pm \\
0.44\end{array}$ & $\begin{array}{l}10.07 \pm \\
0.31\end{array}$ & $\begin{array}{l}9.61 \pm \\
0.44\end{array}$ & $\begin{array}{l}10.57 \pm \\
0.44\end{array}$ & $\begin{array}{l}10.09 \pm \\
0.31\end{array}$ & $\begin{array}{l}9.83 \pm \\
0.44\end{array}$ & $\begin{array}{l}10.82 \pm \\
0.44\end{array}$ & $\begin{array}{l}10.33 \pm \\
0.31\end{array}$ & $\begin{array}{l}10.01 \pm \\
0.12\end{array}$ \\
\hline $\begin{array}{l}\text { Threoni- } \\
\text { ne }\end{array}$ & $\begin{array}{l}6.33 \pm \\
0.35\end{array}$ & $\begin{array}{l}6.96 \pm \\
0.35\end{array}$ & $\begin{array}{l}6.65 \pm \\
0.25\end{array}$ & $\begin{array}{l}6.60 \pm \\
0.35\end{array}$ & $\begin{array}{l}7.26 \pm \\
0.35\end{array}$ & $\begin{array}{l}6.93 \pm \\
0.25\end{array}$ & $\begin{array}{l}6.58 \pm \\
0.35\end{array}$ & $\begin{array}{l}7.24 \pm \\
0.35\end{array}$ & $\begin{array}{l}6.91 \pm \\
0.25\end{array}$ & $\begin{array}{l}6.60 \pm \\
0.35\end{array}$ & $\begin{array}{l}7.26 \pm \\
0.35\end{array}$ & $\begin{array}{l}6.93 \pm \\
0.25\end{array}$ & $\begin{array}{l}6.85 \pm \\
0.09\end{array}$ \\
\hline Serine & $\begin{array}{l}5.50 \pm \\
0.31 \\
\end{array}$ & $\begin{array}{l}6.05 \pm \\
0.31 \\
\end{array}$ & $\begin{array}{l}5.77 \pm \\
0.22 \\
\end{array}$ & $\begin{array}{l}5.20 \pm \\
0.31 \\
\end{array}$ & $\begin{array}{l}5.72 \pm \\
0.31 \\
\end{array}$ & $\begin{array}{l}5.46 \pm \\
0.22 \\
\end{array}$ & $\begin{array}{l}5.30 \pm \\
0.31 \\
\end{array}$ & $\begin{array}{l}5.83 \pm \\
0.31 \\
\end{array}$ & $\begin{array}{l}5.57 \pm \\
0.22 \\
\end{array}$ & $\begin{array}{l}5.40 \pm \\
0.31 \\
\end{array}$ & $\begin{array}{l}5.94 \pm \\
0.31 \\
\end{array}$ & $\begin{array}{l}5.67 \pm \\
0.20 \\
\end{array}$ & $\begin{array}{l}5.62 \pm \\
0.08\end{array}$ \\
\hline Glycine & $\begin{array}{l}3.59 \pm \\
0.22\end{array}$ & $\begin{array}{l}3.94 \pm \\
0.22 \\
\end{array}$ & $\begin{array}{l}3.77 \pm \\
0.15^{\mathrm{B}}\end{array}$ & $\begin{array}{l}4.12 \pm \\
0.22\end{array}$ & $\begin{array}{l}4.53 \pm \\
0.22\end{array}$ & $\begin{array}{l}4.33 \pm \\
0.15^{\mathrm{A}}\end{array}$ & $\begin{array}{l}3.96 \pm \\
0.22 \\
\end{array}$ & $\begin{array}{l}4.36 \pm \\
0.22\end{array}$ & $\begin{array}{l}4.16 \pm \\
0.15^{\mathrm{AB}}\end{array}$ & $\begin{array}{l}4.10 \pm \\
0.22\end{array}$ & $\begin{array}{l}4.51 \pm \\
0.22\end{array}$ & $\begin{array}{l}4.31 \pm \\
0.15^{\mathrm{A}}\end{array}$ & $\begin{array}{l}4.14 \pm \\
0.06\end{array}$ \\
\hline
\end{tabular}




\begin{tabular}{|c|c|c|c|c|c|c|c|c|c|c|c|c|c|}
\hline Alanine & $\begin{array}{l}5.11 \pm \\
0.27\end{array}$ & $\begin{array}{l}5.63 \pm \\
0.27\end{array}$ & $\begin{array}{l}5.38 \pm \\
0.19\end{array}$ & $\begin{array}{l}5.10 \pm \\
0.27\end{array}$ & $\begin{array}{l}5.61 \pm \\
0.27 \\
\end{array}$ & $\begin{array}{l}5.36 \pm \\
0.19 \\
\end{array}$ & $\begin{array}{l}.90 \pm \\
0.27 \\
\end{array}$ & $\begin{array}{l}5.39 \pm \\
0.27 \\
\end{array}$ & $\begin{array}{l}5.15 \pm \\
0.19\end{array}$ & $\begin{array}{l}5.20 \pm \\
0.27\end{array}$ & $\begin{array}{l}5.72 \pm \\
0.27 \\
\end{array}$ & $\begin{array}{l}5.46 \pm \\
0.19\end{array}$ & $\begin{array}{l}5.33 \pm \\
0.07 \\
\end{array}$ \\
\hline Cystine & $\begin{array}{l}2.48 \pm \\
0.15 \\
\end{array}$ & $\begin{array}{l}2.72 \pm \\
0.15 \\
\end{array}$ & $\begin{array}{l}2.60 \pm \\
0.11 \\
\end{array}$ & $\begin{array}{l}2.30 \pm \\
0.15 \\
\end{array}$ & $\begin{array}{l}2.53 \pm \\
0.15 \\
\end{array}$ & $\begin{array}{l}2.42 \pm \\
0.11 \\
\end{array}$ & $\begin{array}{l}2.40 \pm \\
0.15 \\
\end{array}$ & $\begin{array}{l}2.64 \pm \\
0.15 \\
\end{array}$ & $\begin{array}{l}2.52 \pm \\
0.11 \\
\end{array}$ & $\begin{array}{l}2.48 \pm \\
0.14 \\
\end{array}$ & $\begin{array}{l}2.72 \pm \\
0.14 \\
\end{array}$ & $\begin{array}{l}2.60 \pm \\
0.11 \\
\end{array}$ & $\begin{array}{l}2.53 \pm \\
0.04 \\
\end{array}$ \\
\hline Valine & $\begin{array}{l}7.49 \pm \\
0.40 \\
\end{array}$ & $\begin{array}{l}8.24 \pm \\
0.40 \\
\end{array}$ & $\begin{array}{l}7.86 \pm \\
0.28 \\
\end{array}$ & $\begin{array}{l}7.10 \pm \\
0.40 \\
\end{array}$ & $\begin{array}{l}7.81 \pm \\
0.40 \\
\end{array}$ & $\begin{array}{l}7.46 \pm \\
0.28 \\
\end{array}$ & $\begin{array}{l}7.90 \pm \\
0.40 \\
\end{array}$ & $\begin{array}{l}8.69 \pm \\
0.40 \\
\end{array}$ & $\begin{array}{l}8.30 \pm \\
0.28 \\
\end{array}$ & $\begin{array}{l}7.40 \pm \\
0.40 \\
\end{array}$ & $\begin{array}{l}8.14 \pm \\
0.40\end{array}$ & $\begin{array}{l}7.77 \pm \\
0.28\end{array}$ & $\begin{array}{l}7.85 \pm \\
0.11\end{array}$ \\
\hline $\begin{array}{l}\text { Methion } \\
\text {-ine }\end{array}$ & $\begin{array}{l}0.39 \pm \\
0.01^{\mathrm{bc}}\end{array}$ & $\begin{array}{l}0.43 \pm \\
0.01^{\mathrm{a}}\end{array}$ & $\begin{array}{l}0.41 \pm \\
0.01^{\mathrm{A}}\end{array}$ & $\begin{array}{l}0.37 \pm \\
0.01^{\mathrm{c}}\end{array}$ & $\begin{array}{l}0.41 \pm \\
0.01^{\mathrm{ab}}\end{array}$ & $\begin{array}{l}0.39 \pm \\
0.01^{\mathrm{AB}}\end{array}$ & $\begin{array}{l}0.36 \pm \\
0.01^{\mathrm{c}}\end{array}$ & $\begin{array}{l}0.40 \pm \\
0.01^{\mathrm{b}}\end{array}$ & $\begin{array}{l}0.38 \pm \\
0.01^{\mathrm{B}}\end{array}$ & $\begin{array}{l}0.38 \pm \\
0.01^{\mathrm{c}}\end{array}$ & $\begin{array}{l}0.42 \pm \\
0.01^{\mathrm{ab}}\end{array}$ & $\begin{array}{l}0.40 \pm \\
0.01^{\mathrm{AB}}\end{array}$ & $\begin{array}{l}0.39 \pm \\
0.003\end{array}$ \\
\hline $\begin{array}{l}\text { Iso- } \\
\text { leucine }\end{array}$ & $\begin{array}{l}3.23 \pm \\
0.16\end{array}$ & $\begin{array}{l}3.56 \pm \\
0.16\end{array}$ & $\begin{array}{l}3.39 \pm \\
0.11\end{array}$ & $\begin{array}{l}3.10 \pm \\
0.16\end{array}$ & $\begin{array}{l}3.41 \pm \\
0.16\end{array}$ & $\begin{array}{l}3.26 \pm \\
0.11\end{array}$ & $\begin{array}{l}2.96 \pm \\
0.16\end{array}$ & $\begin{array}{l}3.26 \pm \\
0.16\end{array}$ & $\begin{array}{l}3.11 \pm \\
0.11\end{array}$ & $\begin{array}{l}3.00 \pm \\
0.16\end{array}$ & $\begin{array}{l}3.30 \pm \\
0.16\end{array}$ & $\begin{array}{l}3.15 \pm \\
0.11\end{array}$ & $\begin{array}{l}3.23 \pm \\
0.04\end{array}$ \\
\hline Leucine & $\begin{array}{l}9.75 \pm \\
0.44^{\mathrm{a}}\end{array}$ & $\begin{array}{l}10.72 \pm \\
0.44^{\mathrm{a}}\end{array}$ & $\begin{array}{l}10.24 \pm \\
0.31^{\mathrm{A}}\end{array}$ & $\begin{array}{l}8.60 \pm \\
0.44^{\mathrm{b}}\end{array}$ & $\begin{array}{l}9.46 \pm \\
0.44^{\mathrm{ab}}\end{array}$ & $\begin{array}{l}9.03 \pm \\
0.31^{\mathrm{B}}\end{array}$ & $\begin{array}{l}8.46 \pm \\
0.44^{\mathrm{b}}\end{array}$ & $\begin{array}{l}9.31 \pm \\
0.44^{\mathrm{b}}\end{array}$ & $\begin{array}{l}8.89 \pm \\
0.31^{\mathrm{B}}\end{array}$ & $\begin{array}{l}8.20 \pm \\
0.44^{\mathrm{b}}\end{array}$ & $\begin{array}{l}9.02 \pm \\
0.44^{\mathrm{b}}\end{array}$ & $\begin{array}{l}8.61 \pm \\
0.31^{\mathrm{B}}\end{array}$ & $\begin{array}{l}9.19 \pm \\
0.15\end{array}$ \\
\hline $\begin{array}{l}\text { Tyrosin- } \\
\mathrm{e}\end{array}$ & $\begin{array}{l}4.53 \pm \\
0.25 \\
\end{array}$ & $\begin{array}{l}4.98 \pm \\
0.25 \\
\end{array}$ & $\begin{array}{l}4.76 \pm \\
0.18 \\
\end{array}$ & $\begin{array}{l}4.70 \pm \\
0.25 \\
\end{array}$ & $\begin{array}{l}.17 \pm \\
0.25 \\
\end{array}$ & $\begin{array}{l}4.94 \pm \\
0.18 \\
\end{array}$ & $\begin{array}{l}.60 \pm \\
0.25 \\
\end{array}$ & $\begin{array}{l}5.06 \pm \\
0.25 \\
\end{array}$ & $\begin{array}{l}4.83 \pm \\
0.18 \\
\end{array}$ & $\begin{array}{l}4.80 \pm \\
0.25 \\
\end{array}$ & $\begin{array}{l}5.28 \pm \\
0.25 \\
\end{array}$ & $\begin{array}{l}5.04 \pm \\
0.18 \\
\end{array}$ & $\begin{array}{l}4.89 \pm \\
0.06 \\
\end{array}$ \\
\hline $\begin{array}{l}\text { Phenylal } \\
\text { anine }\end{array}$ & $\begin{array}{l}5.53 \pm \\
0.25 \\
\end{array}$ & $\begin{array}{l}4.98 \pm \\
0.25 \\
\end{array}$ & $\begin{array}{l}5.25 \pm \\
0.18 \\
\end{array}$ & $\begin{array}{l}5.40 \pm \\
0.25 \\
\end{array}$ & $\begin{array}{l}4.86 \pm \\
0.25 \\
\end{array}$ & $\begin{array}{l}5.13 \pm \\
0.18 \\
\end{array}$ & $\begin{array}{l}5.50 \pm \\
0.25 \\
\end{array}$ & $\begin{array}{l}4.95 \pm \\
0.25 \\
\end{array}$ & $\begin{array}{l}5.23 \pm \\
0.18 \\
\end{array}$ & $\begin{array}{l}5.10 \pm \\
0.25 \\
\end{array}$ & $\begin{array}{l}4.59 \pm \\
0.25\end{array}$ & $\begin{array}{l}4.85 \pm \\
0.18 \\
\end{array}$ & $\begin{array}{l}5.11 \pm \\
0.07 \\
\end{array}$ \\
\hline $\begin{array}{l}\text { Histidin } \\
\text {-e }\end{array}$ & $\begin{array}{l}3.75 \pm \\
0.20 \\
\end{array}$ & $\begin{array}{l}4.12 \pm \\
0.20 \\
\end{array}$ & $\begin{array}{l}3.93 \pm \\
0.14 \\
\end{array}$ & $\begin{array}{l}3.60 \pm \\
0.20 \\
\end{array}$ & $\begin{array}{l}3.96 \pm \\
0.20 \\
\end{array}$ & $\begin{array}{l}3.78 \pm \\
0.14 \\
\end{array}$ & $\begin{array}{l}3.92 \pm \\
0.20 \\
\end{array}$ & $\begin{array}{l}.31 \pm \\
0.20 \\
\end{array}$ & $\begin{array}{l}4.12 \pm \\
0.14 \\
\end{array}$ & $\begin{array}{l}3.70 \pm \\
0.20 \\
\end{array}$ & $\begin{array}{l}4.07 \pm \\
0.20 \\
\end{array}$ & $\begin{array}{l}3.89 \pm \\
0.14 \\
\end{array}$ & $\begin{array}{l}3.93 \pm \\
0.05 \\
\end{array}$ \\
\hline Lysine & $\begin{array}{l}10.10 \pm \\
0.50 \\
\end{array}$ & $\begin{array}{l}9.09 \pm \\
0.50 \\
\end{array}$ & $\begin{array}{l}9.59 \pm \\
0.35 \\
\end{array}$ & $\begin{array}{l}10.40 \pm \\
0.50 \\
\end{array}$ & $\begin{array}{l}9.36 \pm \\
0.50 \\
\end{array}$ & $\begin{array}{l}9.88 \pm \\
0.35 \\
\end{array}$ & $\begin{array}{l}10.20 \pm \\
0.50 \\
\end{array}$ & $\begin{array}{l}9.18 \pm \\
0.50 \\
\end{array}$ & $\begin{array}{l}9.69 \pm \\
0.35 \\
\end{array}$ & $\begin{array}{l}10.60 \pm \\
0.50\end{array}$ & $\begin{array}{l}9.54 \pm \\
0.50 \\
\end{array}$ & $\begin{array}{l}10.07 \pm \\
0.35\end{array}$ & $\begin{array}{l}9.81 \pm \\
0.13 \\
\end{array}$ \\
\hline $\begin{array}{l}\text { Arginin- } \\
\mathrm{e}\end{array}$ & $\begin{array}{l}4.21 \pm \\
0.26\end{array}$ & $\begin{array}{l}4.62 \pm \\
0.26\end{array}$ & $\begin{array}{l}4.42 \pm \\
0.18\end{array}$ & $\begin{array}{l}4.10 \pm \\
0.26\end{array}$ & $\begin{array}{l}4.51 \pm \\
0.26\end{array}$ & $\begin{array}{l}4.31 \pm \\
0.18\end{array}$ & $\begin{array}{l}4.20 \pm \\
0.26\end{array}$ & $\begin{array}{l}4.62 \pm \\
0.26\end{array}$ & $\begin{array}{l}4.41 \pm \\
0.18\end{array}$ & $\begin{array}{l}4.00 \pm \\
0.26\end{array}$ & $\begin{array}{l}4.40 \pm \\
0.26\end{array}$ & $\begin{array}{l}4.20 \pm \\
0.18\end{array}$ & $\begin{array}{l}4.33 \pm \\
0.06\end{array}$ \\
\hline Proline & $\begin{array}{l}4.31 \pm \\
0.20^{\mathrm{ab}}\end{array}$ & $\begin{array}{l}4.75 \pm \\
0.20^{\mathrm{a}} \\
\end{array}$ & $\begin{array}{l}4.53 \pm \\
0.14^{\mathrm{A}}\end{array}$ & $\begin{array}{l}3.84 \pm \\
0.20^{\mathrm{bc}}\end{array}$ & $\begin{array}{l}4.22 \pm \\
0.20^{\mathrm{b}}\end{array}$ & $\begin{array}{l}4.03 \pm \\
0.14^{\mathrm{B}}\end{array}$ & $\begin{array}{l}3.40 \pm \\
0.20^{c}\end{array}$ & $\begin{array}{l}3.74 \pm \\
0.20^{\mathrm{bc}}\end{array}$ & $\begin{array}{l}3.57 \pm \\
0.14^{\mathrm{C}}\end{array}$ & $\begin{array}{l}3.70 \pm \\
0.20^{\mathrm{bc}}\end{array}$ & $\begin{array}{l}4.07 \pm \\
0.20^{\mathrm{bc}}\end{array}$ & $\begin{array}{l}3.89 \pm \\
0.14^{\mathrm{BC}}\end{array}$ & $\begin{array}{l}4.00 \pm \\
0.07 \\
\end{array}$ \\
\hline
\end{tabular}

Capital super script means differences between averages. Small super script means differences between coarse and fine fibers.

Table 4:-Correlation coefficient between wool amino acids and wool characteristics.

\begin{tabular}{|c|c|c|c|c|c|c|c|c|c|c|c|c|}
\hline Items & 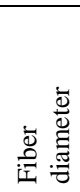 & 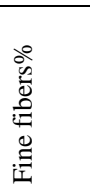 & 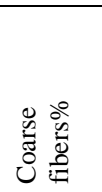 & 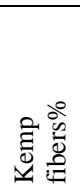 & 导 & 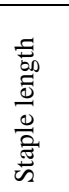 & 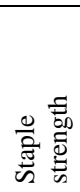 & 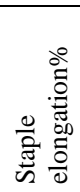 & 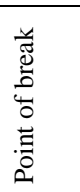 & 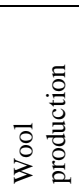 & 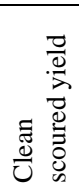 & 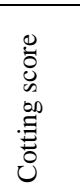 \\
\hline Aspartic & -0.22 & $0.37 * *$ & $-0.37^{* *}$ & -0.12 & -0.09 & -0.2 & 0.15 & $0.32^{*}$ & 0.13 & 0.08 & 0.08 & 0.21 \\
\hline Threonine & -0.1 & 0.26 & -0.26 & -0.09 & -0.07 & -0.18 & 0.19 & $0.33^{*}$ & 0.07 & 0.09 & 0.09 & 0.14 \\
\hline Serine & 0.11 & 0.11 & -0.14 & 0.1 & 0.06 & -0.06 & 0.15 & 0.18 & 0.15 & 0.23 & 0.25 & -0.07 \\
\hline Glutamic & -0.26 & $0.37^{*}$ & $-0.35 *$ & -0.18 & -0.01 & -0.25 & -0.11 & 0.07 & 0.06 & 0.08 & -0.12 & -0.21 \\
\hline Glycine & -0.22 & $0.31^{*}$ & $-0.31 *$ & -0.11 & -0.03 & -0.18 & 0.16 & $0.36^{*}$ & 0.02 & 0.04 & -0.02 & 0.14 \\
\hline Alanine & 0.08 & 0.16 & -0.17 & -0.04 & -0.05 & -0.11 & 0.21 & 0.26 & 0.04 & 0.14 & 0.19 & -0.01 \\
\hline Cystine & -0.14 & $0.30^{*}$ & $-0.32^{*}$ & -0.03 & 0.01 & -0.09 & 0.05 & 0.08 & $0.34^{*}$ & 0.15 & 0.23 & 0.14 \\
\hline Valine & -0.07 & 0.21 & -0.23 & -0.02 & -0.1 & -0.17 & 0.18 & 0.25 & 0.11 & 0.15 & 0.17 & 0.2 \\
\hline Methionine & $0.33^{*}$ & $-0.32 *$ & $0.30^{*}$ & 0.16 & 0.18 & 0.2 & 0.21 & 0.02 & -0.14 & 0.06 & 0.18 & 0.00 \\
\hline Isoleucine & 0.15 & 0.07 & -0.06 & -0.07 & 0.24 & -0.09 & 0.22 & 0.19 & 0.1 & 0.14 & 0.24 & 0.01 \\
\hline Leucine & 0.26 & -0.03 & 0.04 & -0.03 & 0.3 & -0.05 & 0.18 & 0.08 & 0.15 & 0.16 & $0.30^{*}$ & -0.02 \\
\hline Tyrosine & -0.05 & 0.24 & -0.25 & -0.05 & 0.13 & -0.15 & 0.2 & $0.31^{*}$ & 0.04 & 0.12 & 0.13 & 0.05 \\
\hline Phenylalanine & -0.06 & 0.21 & -0.19 & -0.16 & 0.01 & -0.22 & -0.11 & -0.05 & 0.21 & 0.13 & 0.01 & -0.23 \\
\hline Histidine & -0.05 & 0.21 & -0.23 & -0.01 & 0.16 & -0.16 & 0.17 & 0.25 & 0.13 & 0.16 & 0.16 & 0.17 \\
\hline Lysine & -0.11 & 0.29 & -0.29 & -0.13 & -0.02 & -0.23 & -0.11 & -0.01 & 0.08 & 0.13 & -0.02 & $-0.34^{*}$ \\
\hline Arginine & 0.01 & 0.13 & -0.14 & 0.03 & 0.2 & -0.09 & 0.17 & 0.21 & 0.21 & 0.19 & 0.2 & 0.04 \\
\hline Proline & $0.33^{*}$ & -0.08 & 0.1 & -0.04 & $0.31^{*}$ & -0.01 & 0.21 & 0.06 & 0.05 & 0.14 & $0.31 *$ & -0.14 \\
\hline
\end{tabular}

\section{Conclusion:-}

The present study concluded that feeding treated jojoba meal might cause a slight increase in fiber amino acids contents, which in turn make some changes in quantitative and qualitative traits of wool fibers. 


\section{References:-}

1. Abd El-Ghany, W. H. ; F. E. Younis ; W. A. M. Ramadan ; N. H. Ibrahim and H. M. El Shaer (2012): Effect of feeding on salt tolerant plants on physical and chemical properties of coat fibers in sheep. J. Animal and Poultry Prod., Mansoura Univ., Vol.3 (11): 511 - 522.

2. Ashmawy, G. M. (1972): Wool growth and characteristics as affected by nutrition and other environmental factors. Ph. D. Thesis, Fac. Agric., Cairo, Univ., Giza, Egypt.

3. ASTM, (2014): Books of standards Vol.15.04. American Society for Testing and Materials, USA.

4. Azzam, A. H.; Abd El-Ghani, W. H. and El-Ganaieny, M. M. (2002): Relationship of chemical and some physical properties of fibres in sheep and goats. J. Agric. Sci. Mansoura Univ., 27 (8): 5187-5199.

5. Bidinost, F., Roland, D.L., Dodero, A.M., Cano, E.M., Taddeo, H.R., MUELLER J. P., POLI M. A. (2008): Wool quantitative trait loci in Merino sheep. Small Ruminant Research, 74, 113-118.

6. Cardoso, F.A. (1980): Extraction, characterization and functional properties of jojoba proteins. Ph. D. dissertation at the University of Arizona, No. 360.

7. Chapman, R. E. (1960): In The Biology of the Fleece, edited by A. S. Fraser, and B. F. Short, Animal Research Laboratories Technical Paper NO.3. CSIRO, Australia.

8. Duncan, D.B. (1955): Multiple ranges and multiple F-test. Biometrics, 11:1-42.

9. Edriss, M.A., Dashab, G., Ghareha, A., Aghaji, M.A., Nilforoosh, A., MOVASSAGH H. (2007): A study of some physical attributes of Naeini sheep wool for textile industry. Pakistan Journal Biology Science, 10, 9, 415420 .

10. El-Badawi, A. Y.; A.A. Abedo; M. A. El- Ashry; F. I. Helal and M. H. Yacout (2007): Microbial protein enrichment of sugar beet pulp by aerobic fermentation :2- Reflection of tow dietary replacement levels of SBP or fungal treated SBP on ruminal degradation kinetics, rumen fermentation and some hematological parameters of sheep. Egyptian J. Nutrition and Feeds. 10 (2):569-584.

11. El-Bittar, E. M. (2000): Studies on productive performance and wool traits of Egyptian sheep. M. Sc. Thesis. Fac. Agric., Alexandria Univ., Alexandria. Egypt.

12. El-Gabbas, H. M. (1993): Effect of seasons and body positions on the assessments of colour, handle, lustre, bulk and kemp in Barki fleeces. Egypt. J. Anim. Prod., 30 (1): 71-81.

13. El-Gabbas, H. M.; Helal, A. and Al-Betar, E. M. (1999): Wool tenacity in the coarse wool Barki fleeces. Alex. J. agric. Res., 44 (2): 67-83.

14. Guirgis, R. A. (1973): The study of variability in some wool traits in a coarse wool breed of sheep. J. Agric. Sci., Camb., 80: 233-238.

15. Jones, C., Menezes, F., Vella, F. (2004): Auction price anomalies: Evidence from wool auctions in Australia. Econ. Rec., 80, 271-288.

16. Jovanović, R., Dujić, D., Glamocić, D. (2001): Ishrana domaćih životinja, eds., Stylos, Novi Sad, pp. 713.

17. Kearl, L.C. (1982): Nutrient requirement of ruminates in developing countries international feedstuffs Institute Utah Agric .EXP. Station, Utah state Univ. Logan, U.S.A.

18. Kelly, M.J., Swan, A.A., Atkins, K.D. (2007): Optimal use of on-farm fibre diameter measurement and its impact on reproduction in commercial Merino flocks. Australian Journal of Experimental Agriculture, 47, 525-534.

19. Khalel, M. S.; Hassan; A. A.; Shwerab, A.M. and Khayyal, A.A. (2008): Feed evaluation of chemically or biologically treated jojoba meal. Egyptian Journal of Nutrition and Feed, 11 (3):481-495.

20. Khayyal A. A.; Hassan, A. A.; Shwerab, A. M.; Khalel, M. S. and A. Z. Salem, (2009): Effect of feeding diets containing jojoba meal on growth performance of growing rabbits. Egyptian Journal of Nutrition and Feed, 12 (3):475-489.

21. Kulkarni, V. G (1980): Some Physico-chemical studies on the primary and secondary fibers of low-crimp Merino wool. Textile Res. J., 50 (7): 420-422.

22. Manos ,C. G.; P. J. Scherynemeeckers; D. E. Hougue; J. N. Telford; G. S. Stoewsand; D. H. Beerman; J. G. Babish; J. I. Blue; B. S. Shane and D. J. Lisk (1986): Toxicologic studies with lambs fed Jojoba meal supplemented ration. J. Agric. Food Chem., 34:801-805.

23. Masters, D. G., Mata, G., Liu, S. M. and Peterso, A. D. (1998): Influnce of liveweight, liveweight change and diet on wool growth, staple strength and fibre diameter in young sheep. Aust. J. Agric. Res., 49: 269-277.

24. Mata G., Masters D.G., Buscall D., Street K. \& Schlink A.C. (1995): Responses in wool growth, liveweight, glutathione and amino acids, in Merino wethers fed increasing amounts of methionine protected from degradation in the rumen. Australian Journal of Agricultural Research 46, 1189-1204. 
25. Mortimer, S.I., Atkins, K.D., Semple, S.J., Fogarty, $\quad$ N.M. (2010): Predicted responses in Merino sheep from selection combining visually assessed and measured traits. Animal Production Science, 50, 976-982.

26. Motawe, H. F. A. (2005): Chemical evaluation of Jojoba meal. Egypt. J. Nutri and Feeds, 8:861.

27. NgouNgoupayou, J.D. (1982): Nutritional evaluation of jojoba meal. Ph.D. Dissertation, University of Arizona, Tucson, Arizona, Microfilm No. 62.

28. Oxoid, (1982): Oxoid Manual of Culture Media Ingredient and other Laboratory Surface, Turner graphic Ltd. England. $5^{\text {th }}$. Ed.

29. Pajak, J., Zebrowska, T., Zebrowska, H. (1992): Protein content in the diet fattening lambs. 2. The chemical and amino acid composition of the body and utilization of amino acids apparently adsorbed in the small intestine. Journal of Animal and Feed Sciences, 1, 27-36.

30. Pellet,P.L and Young,V.R (1980): Nutritional evaluation of protein foods . published by the United Nation University.

31. Peterson, A. D., Gherardi, S. G., Doyle, P. T. (1998): Components of staple strength in fine and broad wool Merino hoggets run together in a Mediterranean environment. Aust. J. of Agric. Res., 49 (8): 1181-1186.

32. Poppi, D.P., MCLENAN S.R. (2010): Nutritional research to meet future challenges. Animal Production Science, 50, 329-338.

33. Purvis, I.W., Franklin, I.R. (2005): Major genes and QTL influencing wool production and quality: A review. Genetics Selection Evolution, 37, 97- 107.

34. Ralph, I. G. (1984): Effect of pre- and post-natal grain supplements on wool quality. Proc. Aust. Society. Anim. Prod., 15: 549-552.

35. Reis, P.J. (1982): THE IMPORTANCE OF METHIONINE FOR WOOL GROWTH IN SHEEP. Animal Production in Australia. 479-482.

36. Rowe, J.B. (2010): The Australian sheep industry - undergoing transformation. Animal Production Science, 50, 991-997.

37. RUŽIĆ-MUSLIĆ D. (2006): Uticaj razliĉitih izvora proteina u obroku na proizvodne rezultate jagnjadi u tovu. Doktorska disertacija, Poljoprivredni fakultet, Beograd-Zemun, pp. 160.

38. Ryder, M. L. Thea. G. S. (1984): A note on fleece cotting (Felting) in sheep. J. Agric. Sci. Camb.103:369-371.

39. SAS (2008): User's Guide. Statistics. Version 9.2 edition. SAS Institute Inc., Cary, NC.

40. SLEN S. B. (1969): Nutrition in relation to wool production and body growth in sheep. In Nutrition of animals of agricultural importance, SIR DAVID CUTHBERSTON, eds., Pergamon press, London, 1969, 827-848.

41. Sobhy, H. M.; E. A. Mohamed; M. K. Monsour and G.G. Shehab (2003): Influence of jojoba meal supplementation on body gain, function of organs, biochemical parameters associated pathological alteration in male rats. Kafr El-Sheikh Vet. Med. Journal, 1:961-982.

42. Urbaniak, M. (1994): Effect dehydrated Lucerne on lamb performance and protein and energy deposition in the body. Journal of Animal and Feed Sciences, 3, 191-199.

43. Van Boven, M.; R. Busson; M. Cokelaere; G. Flo and E. Decuypere, (2000): 4- Demethyl simmondsin from simmondsia Chinensis. Ind. Crops Prod., 12: 203-208.

44. Verbiscar, A. J. and T. F. Banigan, (1978): Composition of Jojoba seed and foliage.J.Agric Food Chem.,26: 1456.

45. Ward, L. E. (1998): The potential to improve wool quality and on-farm productivity. Animal Production in Australia Vol. 22, Cooperative Research Centre for Premium Quality Wool, Fitzroy, Vic 3065.

46. Warn, L. K., Geenty, K. B., Mceachem, S. (2006): Wool meets meat: Tools for a modern sheep enterprise, CRONJÉ, P., MAXWELL, D.K., eds., Australian Sheep Industry Cooperative Research Centre Conference, Orange, Australia, 60- 69.

47. Wisniak, J. (1987): The chemistry and technology of jojoba oil. Oil Chem. Society, Champaign, Illinois.

48. Wood, E. (2003): Textile properties of wool and other fibres. International Journal of Sheep and Wool Science, Vol. 51.271-290.

49. Zeremski, D., Pavlicević, A., Grubić G. (1989): Uticaj ishrane na prinos i kvalitet vune. XI Savetovanje jugoslovenskog odbora za ovĉarstvo i kozarstvo, 87-100. 